\title{
Issues in Indian Cities Due to Increasing Coverage of Highways: A Case Study of The Sriperumpudur - Poonamalle Stretch in NH4
}

\section{OPHYLIA VINODHINI* AND A. MEENATCHI SUNDARAM}

"Research Scholar, Department of Architecture, National Insititute of Technology, Tiruchirappalli, Tamil Nadu 620015, India

\section{"Email: ophyliagodwin@gmail.com}

Received: September 15th, 2014 | Revised: January 5th, 2015 |Accepted: January 12th, 2015

Published online: January 21, 2015

The Author (s) 2015. This article is published with open access at www.chitkara.edu.in/publications

\begin{abstract}
In 1947, during the year of independence, India's national highway network was approximately $23,000 \mathrm{~km}$. In 1997, national highways had a total length of $34,298 \mathrm{~km}$. As of July 2013 India has multiplied thrice the distance covered by national highways ( $\mathrm{NH}$ ) connecting all the major cities and state capitals. By end of 2017, it is planned that the national highway network should be at $85000 \mathrm{~km}$ (12th Five Year Plan, 2012-17).

Though it is an improvement in the infrastructure, we have to agree that there are many cons in the process. The highways have brought concentric expansion and appearance of sub-centers all along major road intersections. The land-use changes caused by these highways have converted the metropolises to megalopolises, hamlets emerging to bigger cities. The highways are aimed to provide better transport and to link one place to another in a fast mode. "You can start with land use, or you can start with transportation; in either case, the basic feedback leads inevitably to a hierarchy of central places and transportation links connecting them" [Moore and Thorsnes, 1994]. Land-use being the first to impact cities, eventually causes impacts on natural resources and also communities, livelihood, health, safety, etc. The progression of the urban landscape can be considered from a hybrid perception where diverse paradigms were focused in different periods. It is the need of the hour to integrate all the essential paradigms.

This paper provides an overview of the issues and challenges caused by development of highways in India. Rather than covering every aspect of highways, it primarily focuses on those areas that are important from the users' point of view. The paper first reviews the changes in Indian cities due to increasing coverage of highways, followed by a discussion on issues such as Land use split, settlement isolation, identity loss, to mention a few. Building on this background, the paper proposes further researches for the betterment of life in cities affected by Highways.
\end{abstract}

Keywords: Landscape, Highway, Planning, Cities and Highways, Identity, Connectivity

\section{INTRODUCTION}

All through the 1950s and 1960s, the promising American expressway and thoroughfare organizations began to extend, with highway planners paying attention, more or less wholly, on constricted cost-benefit and competence consideration in choosing how to realize their thoughts. In contrast came the

Creative Space Vol. 2, No. 2, January 2015 pp. 197-212

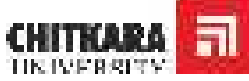

(C)2015 by Chitkara University. All Rights Reserved. 
Vinodhini, O. Sundaram, A.M.
Landscape Architect McHarg's 'Design With Nature', in which he put forward his viewpoint that the structure ought to follow more than just its purpose; it should as well value the natural context in which it is situated.

"The engineer's competence is not the design of highways," McHarg explained, "merely of the structures that compose them -- but only after they have been designed by persons more knowing of man and the land." McHarg's method to resolve the situation was the end-to-end use of map overlays. $\mathrm{McHarg}$ analysed the condition with deference to social values, or, "benefits and costs to society caused by the construction of a multipurpose facility such as a major traffic artery. There were many factors that went into the broad field of social values, including historic, water, forest, wildlife, scenic, recreation, residential, institutional, and land values"(Ian Mcharg, 1960). It is quite distressing that even today our Indian roads are not being worked out by overlaying the factors specified by McHarg in 1950s and 1960s.

\section{INDIAN CITIES AND HIGHWAYS}

As of 2013 the total length of roads in India included National Highways and Expressways of 79,116 km., State Highways of 155,716 km. and, nonhighway roads of 4,455,010 km. As per the CIA World Fact Book, India has a total of 4,689,842 kilometers of road network which is equal to 12 times the distance between earth and moon. The data on National Accounts released by the Central Statistical Organization (CSO), shows that road transport had a share of 4.7 per cent in India's GDP in 2009-10, in comparison to a mere 1 per cent share of the railways.

Change in the city is imminent. It cannot be stopped, but should be planned and moderated for the benefit of the people. Technological revolution, with its dynamic nature, is impacting all aspects of life. It is changing the way we live, work and communicate. There are affirmative and negative impacts in equal measure. The traditional way of planning may not be adequate for the present situation as the work-home relationship is getting blurred and diffused due to restructuring of work and living patterns. Ramachandran (1989) characterizes Indian suburbs as an "uncontrolled mix of industrial development, dumps and obnoxious uses," with the "extension of urban settlement causing conditions in the overtaken villages to deteriorate, both physically and socially." The leapfrog development typical of suburban sprawl tends to follow major highways out of Indian cities to the distance countryside (Pucher et.al, 2005).

\section{ISSUES IN NATIONAL HIGHWAYS}

The major issues as observed through a study of the NH4 are as under: 


\subsection{Changes in Land use}

Changes in Land use are inevitable and are occurring rapidly, primarily impacted by infrastructures facilitating transportation such as highways, roads and railways. Location of Industries and offices, district centers, highways, and road density are all significant in affecting land use change. (Srinivasan, 2005). New Delhi can be taken as the best example to illustrate this.

\subsection{Land Value}

Along the length of highways in Pune, owners of agricultural lands, are forced to sell theiragrarian properties and convert them to landuses such as industrial and real estates and be in charge of these recently misused highway land. The Revenue Department bureaucrats negotiated with the protesting agrarian landowners to build consensus for the Khed SEZ development. Satish Magar, in the Magarpatta case, brought together agrarian landowners in a collective land experiment to build an integrated township. Movements like Narmada Bachao Andolan (NBA) have brought to the fore what happens in the dark corners of the country that are not visited by too many people. We do not know what is happening there or what the tribal and other people in the interior are subjected to when juggernaut projects invade their homeland (Kasturi, 2010). For about 20 years now, there have been changes for the better in the compensation policies for loss of jobs, rehabilitations and resettlements, though much more needs to be done.

\subsection{Loss of Wetlands}

The benefits of marshlands consist of inundation control, recharge of aquifer and storm guard. Marshlands have the ability to uphold excess floodwater for the duration of intense rain. Wetland vegetations help to manage soil erosion, stabilize the shore line and protect human life during or after storms. These keep hold of nutrients by storing eutrophic parameters such as nitrogen and phosphorous, as well helping inclusion of sewage with purifying water supply. The State Highway 109, which connects Old Mahabalipuram Road and Pallavaram in the Pallikaranai Wetland, has shrunk the wetland to a great extent.

\subsection{Impacts on Community Cohesion and Roadside Facilities}

"It is important to realize that local influencers have much to offer as they have probably thought about the problems to be tackled for far longer than any of the "professionals' that are often imposed on the community from outside."
Issues In Indian

Cities Due

To Increasing

Coverage Of

Highways: A Case

Study Of The

Sriperumpudur -

Poonamalle Stretch

In Nh4

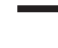


Vinodhini, O. Sundaram, A.M.

(Harper, 1997). Roadside amenities are a necessity to minimize driving-related stresses which are public health issues and play an important role in improving safety, efficiency and quality of the journey. These reduce the fatigue of drivers, stop clear of traffic and minimize collision of vehicles parked on the shoulders. The growth and development of these facilities depend upon the volume of vehicles plying on a particular road. These grow either in a natural way as per need or are planned keeping in view the necessity of a specific road. In India, the facilities location have not been scientifically planned, but growth of these facilities and places is haphazard and is not regulated by the rules framed for the purpose (Singh, 2013).

\section{THE CASE OF NATIONAL HIGHWAY NH4}

The National Highway 4 (NH4) is a major National Highway connecting the metropolitan cities of Mumbai and Chennai, both of which are the emerging megalopolises in West and South India. The NH4 connects Mumbai, Pune, Bangalore, and, Chennai -- four of the ten most heavily populated Indian cities. The length of NH4 is 1,235 km and it commutes through Maharashtra, Karnataka, Andhra Pradesh and Tamil Nadu (Fig. 1). The study area is from Sriperumpudur to Poonamalle, a distance of around $25 \mathrm{~km}$. within the stretch from Kanchipuram - Poonamalle (Fig. 2). Road transport has emerged as the dominant segment in India's transportation sector.

\section{METHODOLOGY}

The research uses past proceedings, problems, matters of concern and specifics. Information has been gathered from written descriptions of past events, present situations and future proposals. Such an effort analyses the existing situation and the proposal which attempts to change the entire scenario. The following were applied in this research paper:

- A study of the parameters leading to development and growth of land values;

- A study of the effects of the unplanned landuses in the study area and the impacts of the same;

- A study of the evolution of changes in the cultural town of Sriperumpudur and the views of people as published in journals and newspapers

- Analysis of the above using secondary sources, including statistical information provided in government sites and previous researches. 


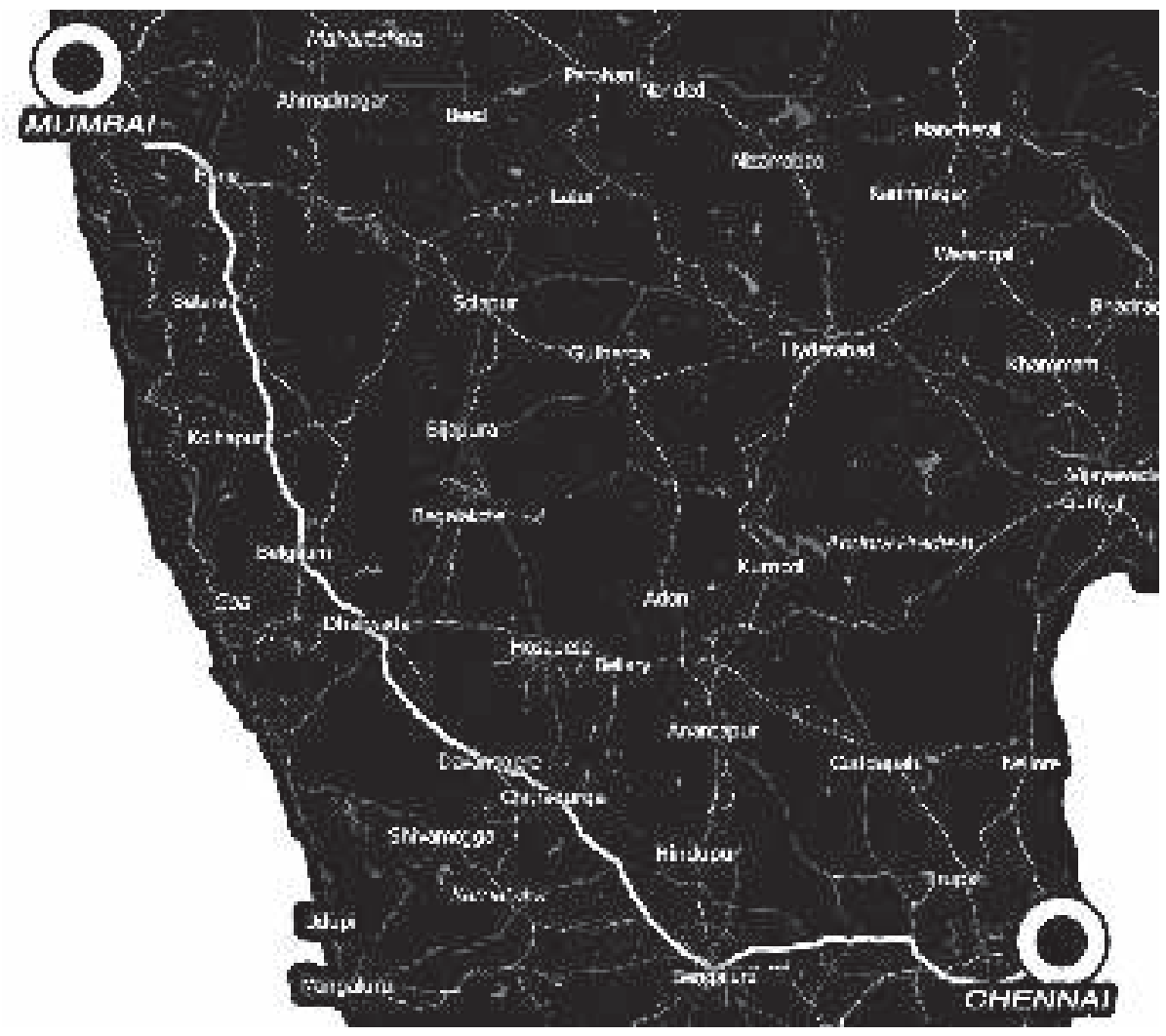

Issues In Indian Cities Due

To Increasing Coverage Of Highways: A Case Study Of The Sriperumpudur Poonamalle Stretch In Nh4

Figure 1: NH4 from west (Mumbai) to southeast (Chennai) India. Source:http://en.wikipedia. org/wiki/National_Highway_4_(India)(old_numbering)\#mediaviewer/File:National_ Highway_4_(India).png

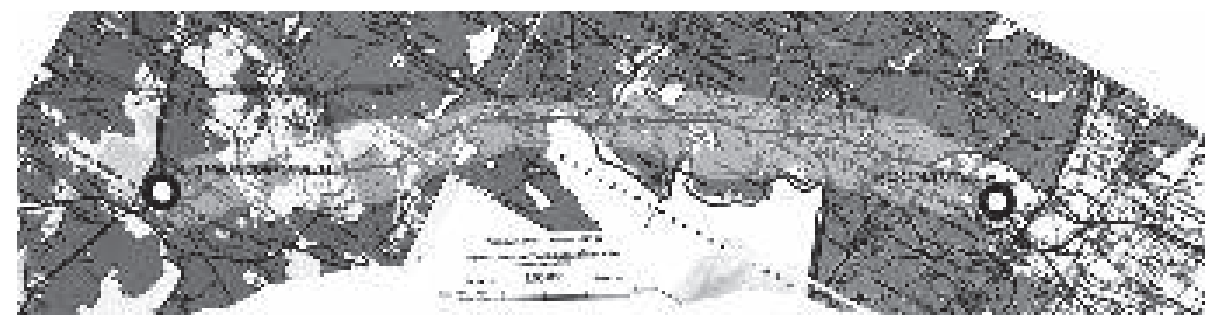

Figure 2: Sriperumpudur to Poonamalle Stretch. Source: Survey of India, Chennai 
Vinodhini, O. Sundaram, A.M.

\section{THE CASE STUDY: SRIPERUMPUDUR TO POONAMALLE STRETCH OF NATIONAL HIGHWAY 4 (NH4)}

As already stated, the NH4 is a major National Highway in Western and Southern India, linking four of the ten most populous Indian cities and passes through the states of Maharashtra, Karnataka, Andhra Pradesh and Tamil Nadu. Within this, through an interconnected growth, a megalopolis ${ }^{1}$ has been formed by the stretch Sriperumpudur to Poonamalle (Fig. 3). With a total length of over $26 \mathrm{~km}$, the stretch links different educational institutions, hospitals, industries, geographic features, diverse local cultures, and natural landscapes from Chennai to suburbs of Chennai.

\subsection{Locational Aspects}

Sriperumpudur is advantageously located on the Chennai-Bangalore highway, at a distance of 40 kilometers from Chennai Egmore. The town of Poonamalle is situated at a distance of 23 kilometers from Fort St. George and 17 kilometers from Sriperumpudur on the Chennai-Bangalore highway (Fig. 4). It is located at the end of the Mount-Poonamalle Road, 11 kilometers from Guindy and 13 kilometers from Chennnai Mofussil Bus Terminus on the Chennai bypass. The closest railway station to the people of Sriperumpudur and Poonamalle is located at Avadi at a distance of nine kilometers from Sriperumpudur. It is also an important halting point for buses starting from Chennnai Mofussil Bus Terminus and going towards Tirupati, Kanchipuram and Vellore. The area is well connected with the mother city Chennai by bus transport system and Para-transit system. The nearest Railway station is Avadi, which is $8 \mathrm{~km}$ away. The proposed extension of MRTS from Velachery would be the nearest railway line for Poonamalle in future.

\subsection{Geographic features}

All along the length, the Sriperumpudur-Poonamalle stretch traverses geographic features such as Sriperumpudur Eri, Pennalum Lake, Thandalam Eri, Chembarambakkam Lake, etc. (Fig. 5). Geologically speaking, Sriperumpudur belongs to the Sriperumpudur Formation which is characterized by arenaceous and argillaceous rock units made of splintery green shale, clays and sandstones with ironstone intercalation and conformably overlying either the Precambrian basement or Precambrian boulder beds and green shales. The beds contain marine intercalations (Murthy, 1961). ]Their litho logic suites and fossil fauna are suggestive of deposition under shallow and brackish conditions, probably close to the seashore (Sastry et.al., 1974).

${ }^{1}$ A megalopolis is typically defined as a chain of roughly adjacent metropolitan areas. The term was used by Patrick Geddes in 1915 in his book "Cities in Evolution". 


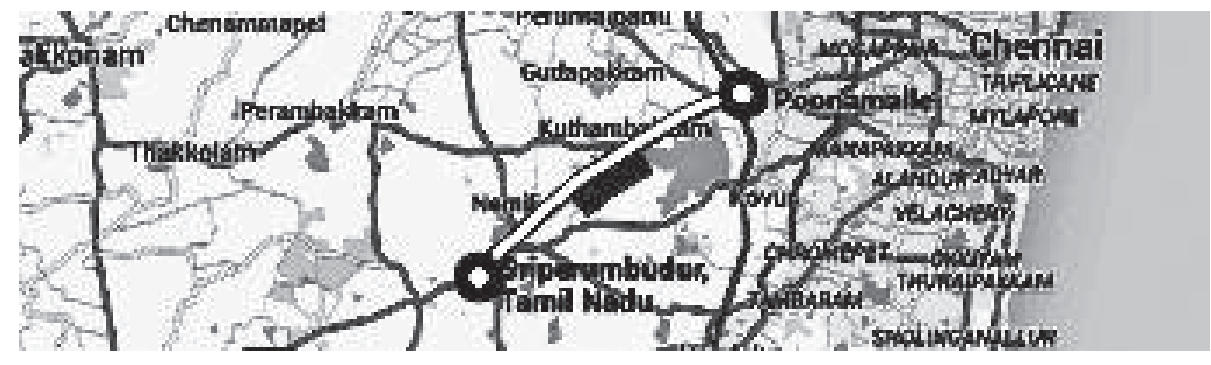

Figure 3: Location of the stretch Sriperumpudur to Poonamalle from the coast (Image Source: Located by researcher on map from www.maps.google.com)

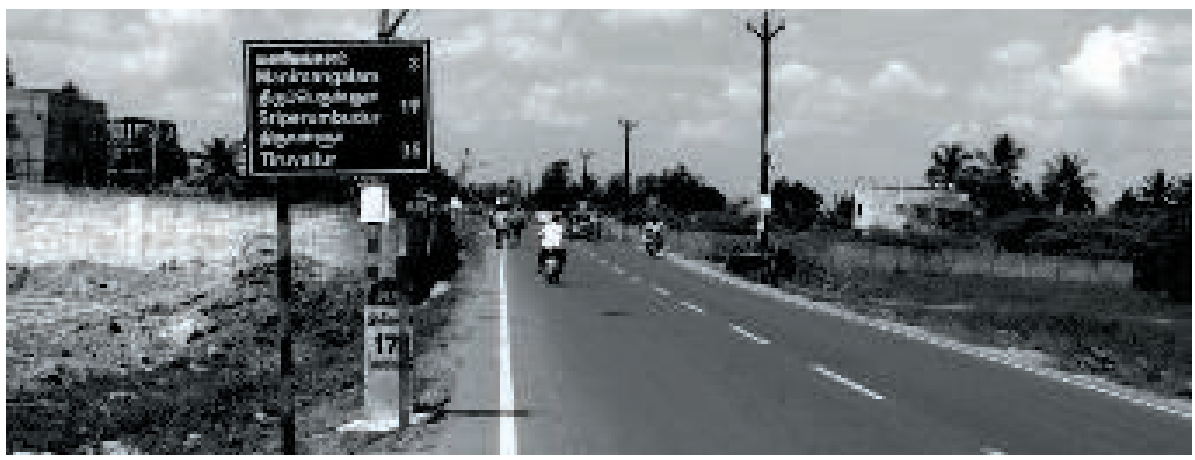

Figure 4: Approach road from Tambaram, Chennai (Image Source: Author)

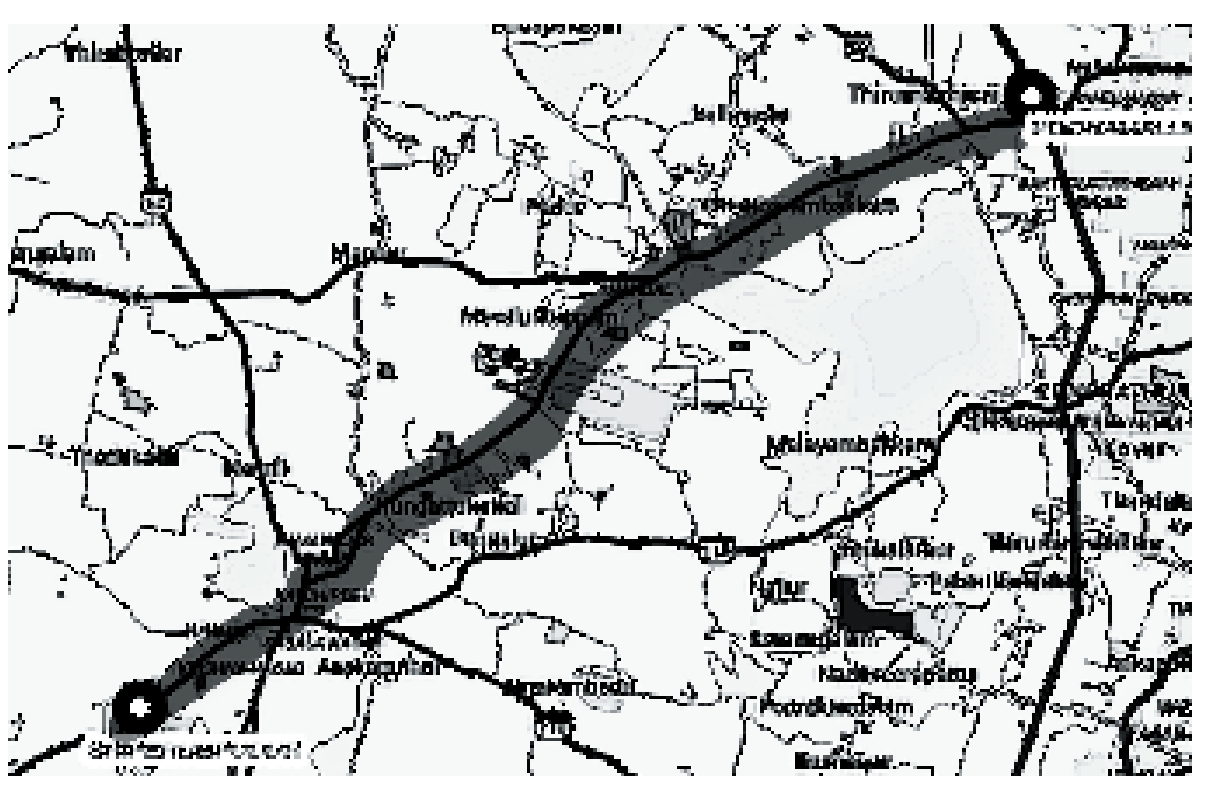

Figure 5: Location of the stretch Sriperumpudur to Poonamalle with Chembarambakkam Tank (Image Source: Located by researcher on map from www.maps.google.com)
Issues In Indian

Cities Due

To Increasing

Coverage Of

Highways: A Case

Study Of The

Sriperumpudur Poonamalle Stretch In Nh4 
Vinodhini, O.

Sundaram, A.M.

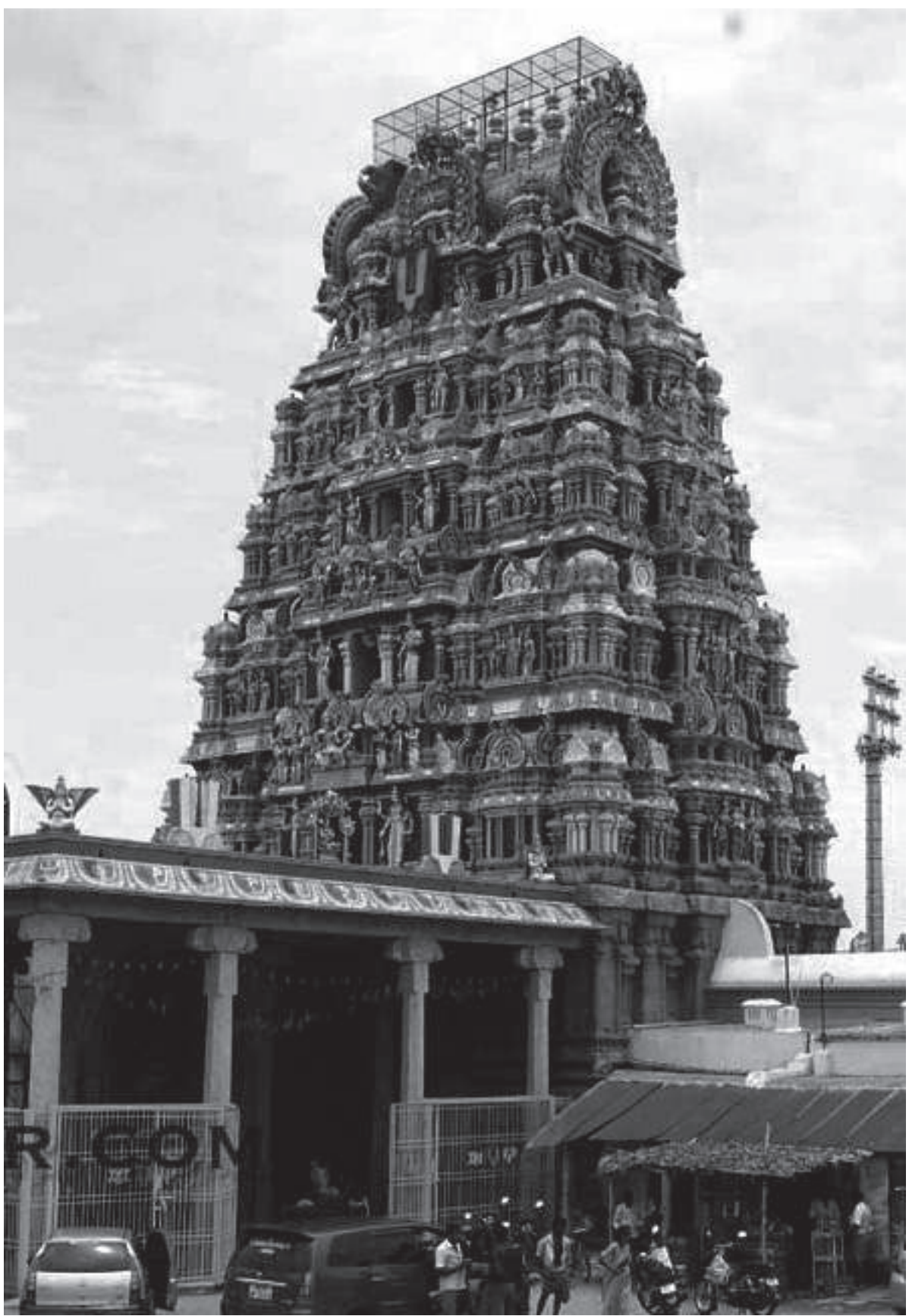

Fig. 6: Adhikesava Temple Sriperumpudur (Image Source: http://temple.dinamalar.com) 


\subsection{CULTURAL HERITAGE}

Sriperumpudur town, earlier known as 'Boothaburi,' was originally an agrarian community dating back to the first millennia. The town has a rich cultural and religious heritage and is well known as the birth place of the Vaishnavite Saint Shri Ramanujar. As in the case of many ancient settlements of Tamil Nadu, the town has evolved around the temple and tank of the Adhikesava Perumal Kovil (Fig. 6). The town is endowed with many structures of heritage significance apart from the Adhikesava Perumal temple, namely, the Boothabureeswarar Temple, Manavala Maamuni temple, Thaan Thondri Amman Temple and many Mandapams of heritage value. Poonamalle, too, has a rich cultural history with its two temples built during Pallava period. Poonamalle was officially a battalion town meant for the British Army stationed with several British military units during the Pre-Independence period.

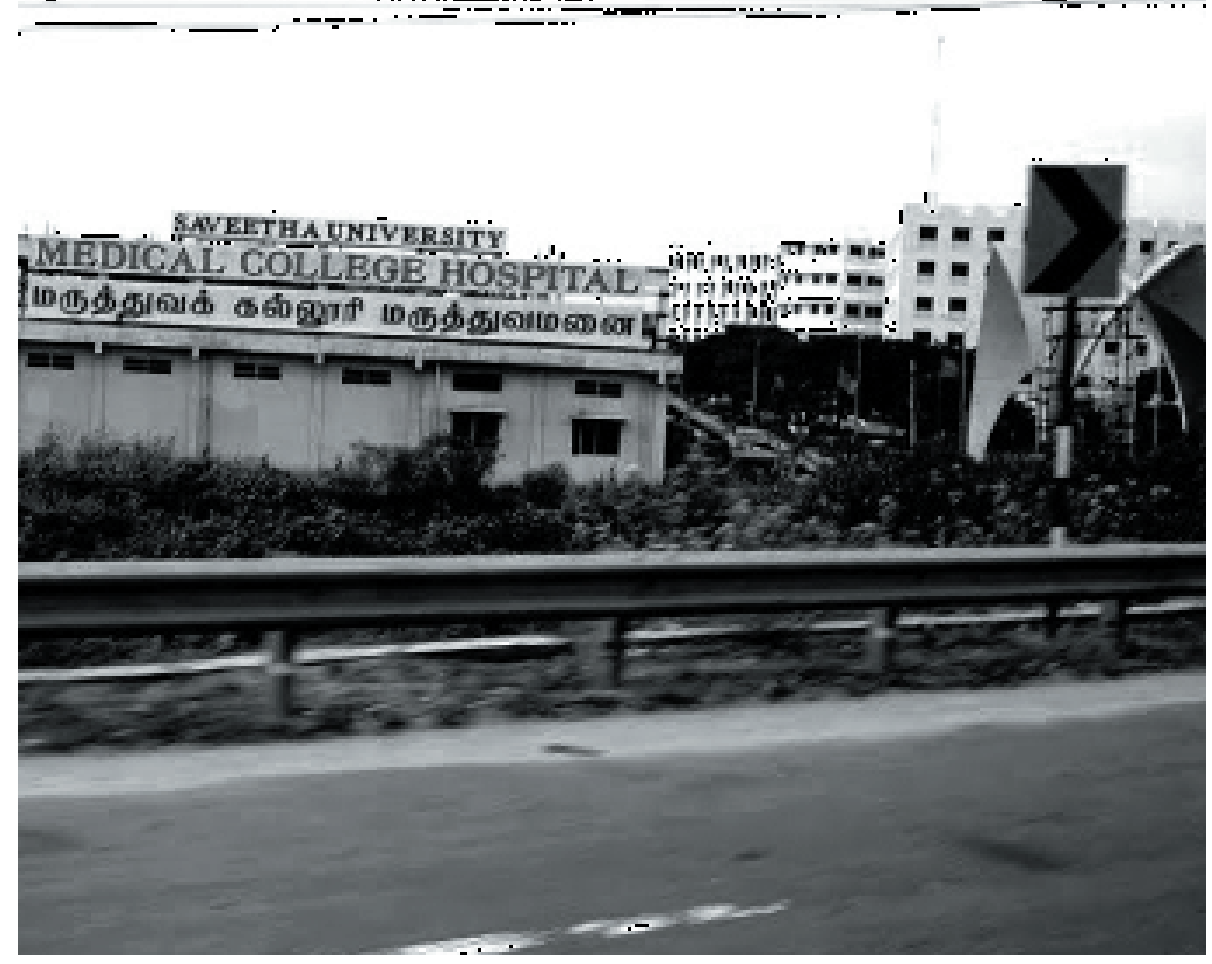

Fig. 7: Institutional landuse Saveetha Medical College, Sriperumpudur (Source: Author)
Issues In Indian Cities Due To Increasing Coverage Of Highways: A Case Study Of The Sriperumpudur Poonamalle Stretch In Nh4 
Vinodhini, O.

Sundaram, A.M.

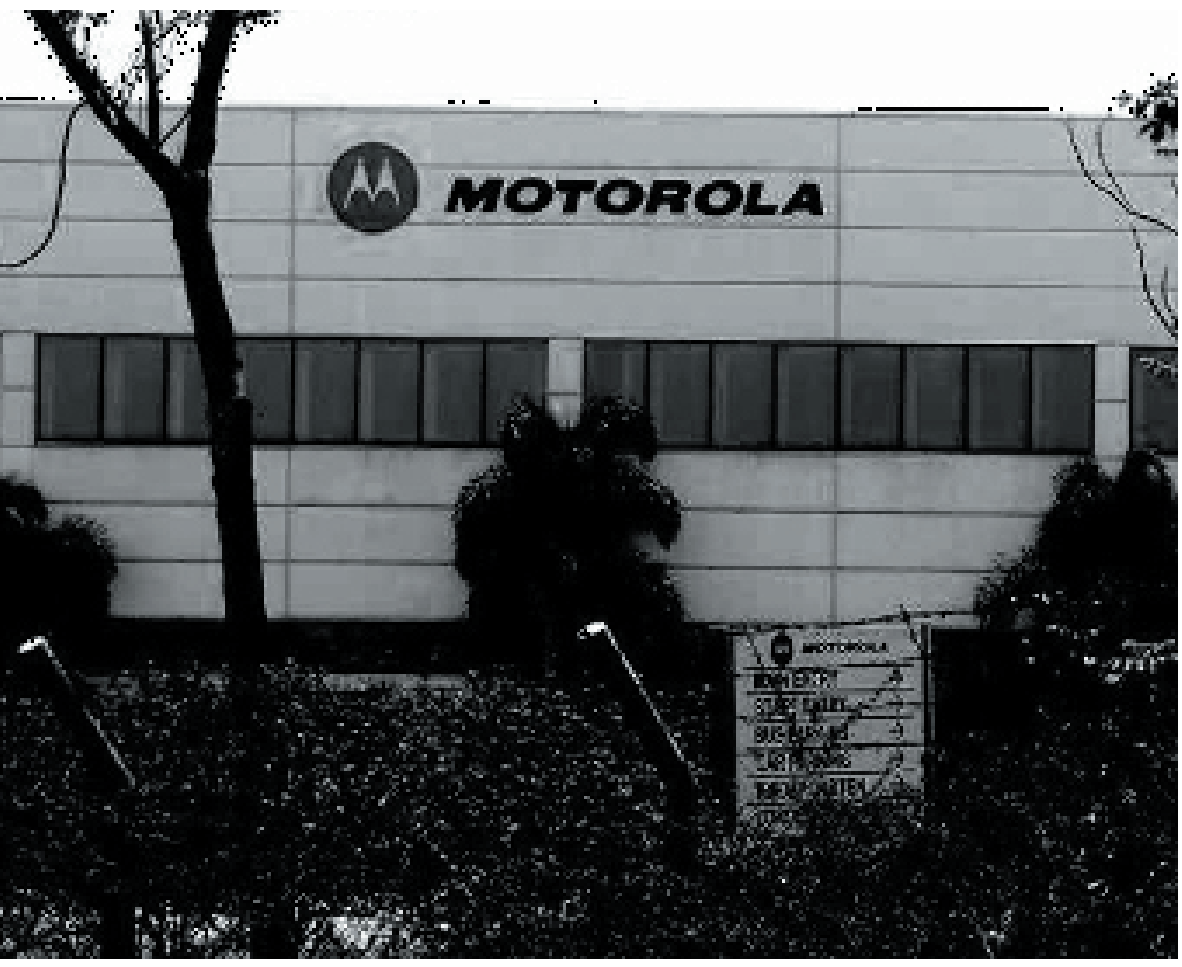

Fig. 8: Industrial landuse (Image Source: Author)

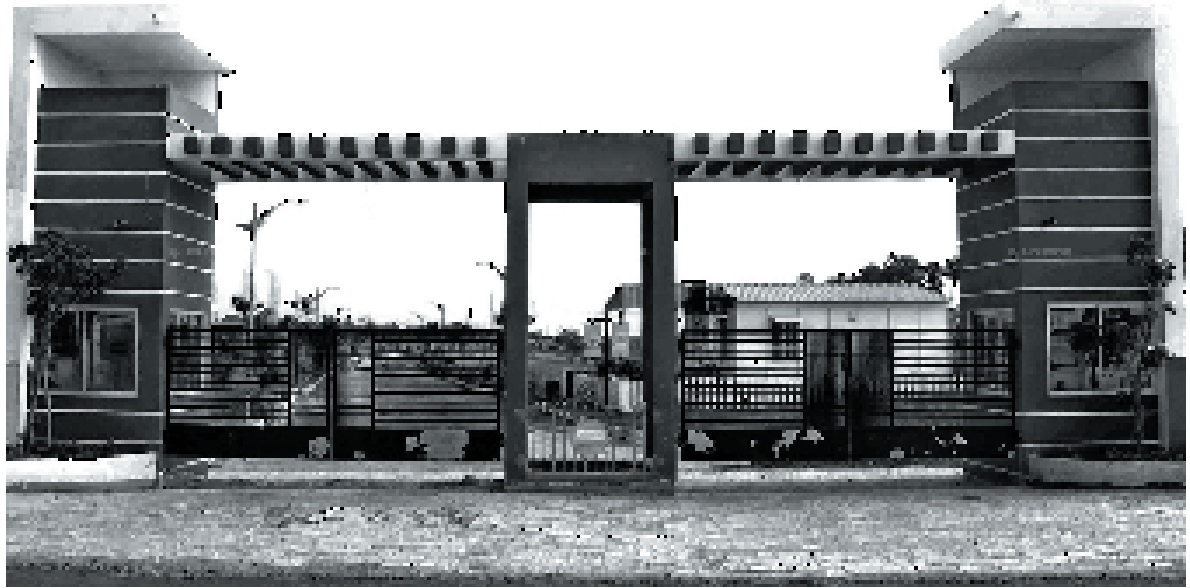

Fig. 7: Residential landuse (Image Source: Author) 


\subsection{Changes in Landuse}

Land use development patterns (also called urban form, built environment, community design, spatial development, and urban geography) refer to human use of the earth's surface, including the location, type and design of infrastructure such as roads and buildings. Land use patterns can have diverse economic, social and environmental impacts: some require less impervious surface (buildings and pavement) per capita and so preserve more open space (gardens, farmland and natural habitat), and some are more accessible and so reduce transportation costs to businesses and consumers. The decisions taken for enhancing transportation planning affect existing land uses (Figs. $7,8,9)$. Nevertheless, the amount of land used for constructing roads greatly affects the people of the land. For example, expanding urban highways increases pavement area, and encourages more dispersed, automobile-oriented development (sprawl), while walking; cycling and public transit improvements encourage compact, infill development (smart growth).

\subsection{Changes in Landvalues}

The development of SEZ has caused dramatic rise in the land values in Sriperumpudur

\begin{tabular}{llll}
\hline SI.No & $\begin{array}{l}\text { Villages under } \\
\text { Sriperumbudur Taluk }\end{array}$ & $\begin{array}{l}\text { Land value in Rs. } \\
\text { per cent (Before } \\
\text { establishment of SEZ) }\end{array}$ & $\begin{array}{l}\text { Guide line values } \\
\text { in Rs. per cent } \\
\text { (2007) }\end{array}$ \\
\hline 1 & Sriperambudur & 2500 & $\begin{array}{l}109000 \text { to } \\
435000\end{array}$ \\
2 & Mambakkam & 10000 & - \\
3 & Pondur & 12500 & 28000 to 108000 \\
4 & Araneri & 950 & - \\
5 & Thirumangalam & 1500 & 17000 to 45000 \\
6 & Vadamangalam & 900 & 18000 to 87000 \\
\hline
\end{tabular}

Table 1: Land values in Sriperumpudur Taluk - SEZ. (Source: Comprehensive Development Plan for Sriperumpudur)
Issues In Indian Cities Due

To Increasing

Coverage Of

Highways: A Case

Study Of The

Sriperumpudur -

Poonamalle Stretch

In Nh4 
Vinodhini, O. Sundaram, A.M.

\begin{tabular}{lll}
\hline Sl. No. & Name of the road stretch & Guide Line value \\
\hline (i) & $\begin{array}{l}\text { Along Thiruvottiyur High Road } \\
\text { and GNT Road }\end{array}$ & Rs. 250 to Rs. 1200 \\
(ii) & Along CTH Road & Rs. 250 to Rs. 1500 \\
(iii) & Along Poonamallee High Road & Rs. 565 to Rs. 1500 \\
(iv) & Along GST Road & Rs. 1000 to Rs. 6900 \\
(v) & $\begin{array}{l}\text { In between Poonamallee High } \\
\text { Road and GST Road }\end{array}$ & Rs. 250 to Rs. 1950 \\
(vi) & Along OMR \& ECR & Rs. 2000 to Rs. 4410 \\
(vii) & $\begin{array}{l}\text { Along Velachery - Tambaram } \\
\end{array}$ & Road and Medavakkam Road \\
\hline
\end{tabular}

Table 2: Guideline Value of Lands along Important Roads.

Source: http://www.tnreginet.net/igr/gvaluemainpage.asp?yr=2002 and http://www.tnreginet.net/test1/gvaluemainpage2007.asp

The above table depicts the change in landvalues along the Poonamalle high road and by-pass road connecting GST road. There is a great increase from Rs. 565 to Rs. 1500 and Rs 250 to Rs. 1950.

\subsection{Identity Loss}

Regardless of the deep ethnicity of cities along the highway, the local identity can barely be found (apart from the text on the highway signage) owing to the integrated structures and organization of the highway as well as the substantial distance of the highway from the time-honoured city cores. Each building unit on the highway seems to be a replica of something prepared elsewhere and it is almost close to impossible to identify the location by the appearance of the highway.

\subsection{Design Approaches for the Sriperumpudur to Poonamalle stretch}

The approach of the National Highways Authority of India (NHAI) is more focused on accommodating the increasing number of vehicles and frequency of trips. The problems caused due to unplanned land uses, increasing land values and loss of cultural identity of these historic towns are not considered in the rush for increasing the highway infrastructure in these cities. 


\section{CONCLUSION}

Land-use should be spread to reduce vehicle trips and pedestrian vehicle conflicts. These would cause indirect land use effects and the induced travel demand it results in (Uri Avin et.al., 2007). Networks should be classified into a chain of command with the importance on speed supervision. Layouts of roads in residential areas should be designed to keep out through traffic and keep speeds down to appropriate levels. Another major problem on the Highways is the amalgamation of traffic. Vehicles travelling in different speed and with difference in number of users, commodity, material conveyed, animals also utitlise the highways. We can sometimes point to animals grazing on the median too. This increases traffic time, congestion, pollution and road accidents. Density and clusters affect the distance that public has to pass through, as also the modes of transport, including walking and cycling. Land use mix affects trip distance and the option of non-mechanical transport. Situating service, trade and communal facilities in a single, secure, walkable, profit-making center increases the possibility of a good transportation exercise and allows citizens to undertake private and work-related tasks devoid of driving. Parking organization affects the comparative cost and expediency of driving, and affects land use concentration, ease of access and walkability. Street connectivity affects ease of access, as well as the amount of travel necessary to get to destinations and the expediency of cycling and walking. Passage Oriented Development makes passage comparatively more suitable, and can be a channel for further land-use change.

\section{REFERENCES}

[1] Bacon, E. (1967). Design of Cities. New York: Viking Press.

[2] BATTY, M. (2009). A Digital Breeder for Designing Cities. Architectural Design, 79(4), pp.4649. Available from: http://dx.doi.org/10.1002/ad.916

[3] BERRY, B. and OKULICZ-KOZARYN, A. (2009). Dissatisfaction with city life: A new look at some old questions. Cities, 26(3), pp.117-124. http://dx.doi.org/10.1016/j.cities.2009.01.005

[4] FAINSTEIN, S. AND CAMPBELL, S. (2011). Readings in Urban Theory. Chicester, West Sussex: Wiley-Blackwell.

[5] GEDDES, R. (1997). Cities in Our Future. Washington, D.C.: Island Press.

[6] GORDON, D. (2011). Urban Design Reclaimed: Tools, Techniques and Strategies for Planners Grid/ Street/ Place: Elements of Sustainable Urban Districts. Journal of Urban Design, 16(03), pp.427-429. http://dx.doi.org/10.1080/13574809.2011.573296

[7] HALL, P. (1988). Cities of Tomorrow. Oxford, UK: Blackwell. Available from: http://dx.doi. org/10.1016/0264-2751(88)90001-7

[8] HARPER, P. (1997) The Importance of Community Involvement in Sustainable Tourism Development, in STABLER, M.J.(Ed) Tourism and Sustainability: Principles to Practice CAB International, Wallingford, UK 1997 p 143-149
Issues In Indian Cities Due

To Increasing

Coverage Of

Highways: A Case

Study Of The

Sriperumpudur Poonamalle Stretch In Nh4 
Vinodhini, O. Sundaram, M.
[9] HEATHCOTE, E. (2011). Old Age and the City. BMJ, 343(jul25 1), pp.d4418-d4418.

[10] HUCK, F., FALES, C. and RAHMAN, Z. (1997). Visual Communication. Boston: Kluwer Academic Publishers. Available from: http://dx.doi.org/10.1007/978-1-4757-2568-1

[11] KAHN, M. (2006). Green Cities. Washington, D.C.: Brookings Institution Press.

[12] KASTURI, K. (2010) Mega Project Development: Issues in Land Acquisition. ORF Seminar Series, Volume 1 Issue 5

[13] KENT, R. (1993). Determining scenic quality along highways: a cognitive approach. Landscape and Urban Planning, 27(1), pp.29-45. Available from: http://dx.doi.org/10.1016/01692046(93)90026-A

[14] LITMAN, T. and STEELE, R. (2011). Land use Impacts on Transport. Victoria, B.C.: Victoria Transport Policy Institute.

[15] LYNCH, K. (1960). The Image of the City. Cambridge, Mass.: MIT Press.

[16] Lynch, K. (1981). A Theory of Good City Form. Cambridge, Mass.: MIT Press.

[17] MOORE, T. and THORSNES, P. (1994). The transportation/land use connection. Chicago, IL (1313 E. 60th St., Chicago 60637): American Planning Association, Planning Advisory Service.

[18] MOUDON, A. (1997). Effects of site design on pedestrian travel in mixed-use, medium-density environments. Washington, D.C.: Transportation Research Board.

[19] MOUGHTIN, C. (1996). Urban Design. Oxford: Butterworth Architecture.

[20] MUMFORD, L. (1961). The City in History. New York: Harcourt, Brace \& World.

[21] MURTHY, N.G.K. and SASTRY, V.V. (1961). "Foraminifera from the Sriperumpudur beds near Madras". Indian Minerals (Geological Survey of India) 14: 214-15

[22] PUCHER, J., KORATTYSWAROPAM, N., MITTAL, N. and ITTYERAH, N. (2005). Urban transport crisis in India. Transport Policy, 12(3), pp.185-198. Available from: http://dx.doi. org/10.1016/j.tranpol.2005.02.008

[23] RAMACHANDRAN, R. (1989). Urbanization and urban systems in India. Delhi: Oxford University Press.

[24] ROGERS, P. AND PADAM, S. (2001). Transportation, land use, and environment. Cambridge, USA: Division of Engineering and Applied Sciences, Harvard University and Centre for Transport Policy and Economics, Central Institute of Road Transport, Pune, India.

[25] SASTRY, V.V., RAJU, A.T.R., SINGH, R.N. and VENKATACHALA, B.S. (1974) Evolution of the Mesozoic sedimentary basins on the east- coast of India. APEA Journal, 29-41.

[26] SINGH.K. (2013) Quality and Availability of Passenger Facilities along Selected National Highways in Haryana and Its Impact on Highway Users and Surrounding Communities

[27] SPREIREGEN, P. (1965). Urban design: the architecture of towns and cities. New York: McGraw-Hill.

[28] SRINIVASAN, S. (2005). Linking land use and transportation in a rapidly urbanizing context: A study in Delhi, India. Transportation, 32(1), pp.87-104. Available from: http://dx.doi. org/10.1007/s11116-004-2216-y

[29] TANEJA, K. and SINGH, R. (1971). Morphology of Indian cities. Varanasi: National Geographical Society of India.

[30] TOPCU, M. and KUBAT, A. (2012). Old and New City: morphological analysis of Antakya. In: Eighth International Space Syntax Symposium. Santiago de Chile.

[31] TRANCIK, R. (1986). Finding lost space. New York: Van Nostrand Reinhold. 
[32] URI AVIN, PB, CERVERO, R., MOORE, T., CHRISTOPHER DORNEY, PB. (2007), Forecasting Indirect Land Use Effects of Transportation Project, American Association of State Highway and Transportation Officials(AASHTO) Standing Committee on the Environment. A report for NCHRP Project 25-25, Task22, National Cooperative Highway Research Program, Transportation Research Board,December, 2007, pp.71- 79

[33] WALL, E. and WATERMAN, T. (2010). Urban design. Lausanne: AVA Academia.

[34] MCHARG, I., Overlay Maps and the Evaluation of Social and Environmental Costs of Land Use Change. 2015. [ONLINE] Available at:http://www.csiss.org/classics/content/23.
Issues In Indian Cities Due

To Increasing Coverage Of Highways: A Case Study Of The Sriperumpudur Poonamalle Stretch In $\mathrm{Nh} 4$ 